\title{
Association of anticardiolipin antibodies with vascular injury: possible mechanisms
}

\author{
Y S Haviv
}

Lupus anticoagulant, first observed in 1952 in two patients with systemic lupus erythematosus (SLE), ${ }^{1}$ was linked to a phospholipid antigen when positive Wassermann tests for syphilis coincided with the lupus anticoagulant, documenting the lipid nature of the antigen. Bowie and colleagues were the first to unravel the paradoxical prothrombotic tendency of patients with positive lupus anticoagulant. ${ }^{2}$ This prothrombotic tendency that often results in microscopic thromboembolism is unique in being detected by positive serological tests. While immunoglobulins of isotypes IgG or IgM may have the lupus anticoagulant effect, the significance of IgA isotypes is not clear. These antibodies interfere with the in vitro phospholipid dependent coagulation tests. Lupus anticoagulant activity is documented by inability to correct prolonged activated partial thromboplastin time (aPTT) with normal plasma, and the necessity of phospholipid for the inhibition. Lupus anticoagulant belongs to a family of antiphospholipid antibodies (aPL) that also includes reagin and anticardiolipin antibodies $(\mathrm{aCL})$, and the recently recognised antibody to beta-2-glycoprotein I $(\beta 2 \mathrm{GpI})$. $\mathrm{aCL}$ and lupus anticoagulant are distinct and complementary tests for aPL. In patients with aPL syndrome, $60 \%$ will be positive for both lupus anticoagulant and aCL, while either test will be positive in the rest of the patients.

Until recently, the most sensitive test for aPL was aCL. This ELISA test determines antibody binding to solid plates coated with cardiolipin or other negatively charged phospholipids. Recently, aPL were shown to be specific for phospholipid-protein complexes, ${ }^{3}$ where the protein is identical with being $\beta 2 \mathrm{GpI},{ }^{45}$ or less often prothrombin, protein $\mathrm{C}$, or protein $\mathrm{S}^{6-8}$

aPL may be either autoimmune or alloimmune. The latter appear transiently after an infection or associated with a lymphoproliferative disorder, and do not usually have clinical implications.

The former are persistent and may be primary, as in the aPL syndrome, or secondary to drugs, SLE (where $40 \%$ of patients have either lupus anticoagulant or aCL), or other collagen vascular disease. Autoimmune aPL rather than alloimmune, are associated with hypercoagulability. Although in general thrombotic episodes may occur anywhere in the vascular tree, in a single patient the event is either venous or arterial and does not cross react. Clinical manifestations of aPL include venous and arterial thromboembolic phenomena, such as miscarriage, thrombocytopenia, neurological manifestations, deep vein thromboses and pulmonary embolism, or arterial thromboses. Pre-eclampsia has also been reported to be associated with aPL. The syndrome may be either a part of a systemic disorder, classically SLE, or a primary disorder, called the antiphospholipid syndrome. While aPL are in fact a family of antibodies, the incidental finding of positive serology is yet to be determined. However, correlation of incidental aPL with thrombotic episodes has not been documented in large scale surveys. After the discovery of aPL, several mechanisms have been proposed for the pathogenesis of its prothrombotic tendency, such as reduced inhibition of activated factor $\mathrm{V},{ }^{6-8}$ platelet activation, ${ }^{910}$ endothelial injury, ${ }^{11}$ and direct recognition of phospholipids. However, the probable primary mechanism of aPL hypercoagulablility has recently been elucidated. $\beta 2 \mathrm{GpI}$ is a $50 \mathrm{kD}$ protein with a natural anticoagulant activity. It inhibits surface mediated activation of prekalikrein and factor XII, activated factor $\mathrm{V}$, and platelet aggregation. ${ }^{12-14}$ $\beta 2 \mathrm{GpI}$ binds to phospholipid and optimises the reaction in autoimmune diseases but not after infections. ${ }^{13}$ aCL activity is dependent on the combination of cardiolipin and $\beta 2 \mathrm{GpI}$, with the phospholipid binding protein complex playing the major immunogenic part in the production of aCL specifically and the aPL syndrome in general. ${ }^{15} 16$

Moreover, $\beta 2 \mathrm{GpI}$ can discriminate between autoimmune aCL and alloimmune aCL, ${ }^{17}$ by enhancing the cardiolipin binding in aPL syndrome and inhibiting the cardiolipin binding of post-infectious aCL. These nonpathogenic alloimmune aPL may react with solid phase and fluid phase cardiolipin even in the absence of $\beta 2 \mathrm{GpI}$, unlike autoimmune aCL. ${ }^{18}$

The prevalence of aCL in arbitrary internal medicine patients is $11 \%,{ }^{19}$ a rate similar to aCL found in young adults with premature atherosclerosis. ${ }^{20}$ However, $26 \%$ of a general population of vascular surgery patients are aCL positive. ${ }^{21}$ Higher prevalence of aCL may also be found in patients with recurrent vascular insults, such as dialysis patients. ${ }^{22-26}$ In contrast, the proportion of positive aCL in the general population is below $10 \% .^{19}$

The mechanisms involved in the association between aCL and vascular disease may include one or any combination of endothelial activation, atherogenic, immune, or apoptotic processes in genetically susceptible subjects.

\section{Endothelial activation}

aCL have been documented in subendothelial cardiac deposits, ${ }^{27}$ while histological findings in aCL associated brain infarcts are noninflammatory and consist of endothelial hyperplasia and thrombosis. ${ }^{28}$ The mechanism of aCL associated vasculopathy includes 
interaction of endothelial cells with platelets and aPL, to promote a cascade of reactions yielding recurrent local thromboses and intimal hyperplasia. Anticardiolipin autoantibodies prompt a prothrombotic endothelial surface, ${ }^{29}$ while the $\beta 2 \mathrm{GpI}-\mathrm{aCL}$ antibody complex activates endothelium in vitro. ${ }^{30}$

Antiphospholipid antibody binding to endothelium induces in vitro up-regulation of adhesion molecules, such as intracellular adhesion molecule-1 and extracellular adhesion molecule-1, stimulated by an autocrine loop of interleukin (IL) $-1 \beta$ secretion. ${ }^{31}$

Platelet-endothelium interaction mediated by aCL may alter thromboxane A2prostacyclin balance, leading to enhanced thrombosis and vasoconstriction. ${ }^{32}$ Patients with renal failure may be especially prone to this effect because uraemia is associated with the inhibition of nitric oxide synthase, ${ }^{33}$ and because of the effect of hypertension and advanced glycosylation end products on endothelial cell relaxation and proliferation, and on endothelin production in vitro. ${ }^{34} 35$

Endothelin-1 which induces vasospasm and arterial occlusion, is released by endothelium in response to aPL. ${ }^{36}$ The molecular mechanism may involve endothelial adhesion via $\beta 2 \mathrm{GpI}$ lysine 286, and activation of endothelial cells by the complex of aCL and anti- $\beta 2 \mathrm{GpI},{ }^{37}$ resulting in inhibition of endothelial antithrombotic effect and vascular tone relaxation. A mechanism similar to heparin induced thrombocytopenia has also been suggested for aCL associated vascular occlusion and thrombosis. ${ }^{38}$

In addition to endothelial induced thrombosis, intimal hyperplasia plays a major part in vascular occlusions. Homocysteine induces endothelial modulated vasoconstriction and growth of vascular smooth muscle cells, ${ }^{39}$ and endothelin, prompted by aCL, enhances endothelial cell proliferation in vitro. ${ }^{34}$

Vascular endothelial growth factor (VEGF), also named vascular permeability factor (VPF), may be an important regulator of angiogenesis in inflammation. ${ }^{40} \mathrm{VEGF} / \mathrm{VPF}$ may be extensively expresses in wall or plaques of medium to large vessels and in narrowed atherosclerotic arteries. ${ }^{41}$ However, the precise pathogenic role of VEGF in vascular diseases is yet to be determined.

Initial endothelial damage exposes anionic phospholipids that react with phospholipid binding proteins, such as $\beta 2 \mathrm{GpI}$ or prothrombin. The simultaneous binding of aCL to cellular Fc receptor and phospholipid protein complex induces endothelial-platelet interaction resulting in thrombosis.

\section{Accelerated atherosclerosis}

An intriguing possible pathogenetic role for aCL in vasculopathy is the cross reaction with oxidised low density lipoprotein (LDL) antibodies. Oxidised LDL may induce IL-1 secretion by macrophages, resulting in smooth muscle proliferation. Oxidative modification of LDL plays a major part in atherogenesis via foam cell formation and cell cytotoxicity, with uptake of oxidised LDL-antioxidised LDL complexes by macrophages. As phospholipids bear structural resemblance to LDL, aCL may cross react with antioxidised LDL. ${ }^{42}$

On the one hand, oxidised LDL aggravates in vitro the clinical manifestations of aPL, ${ }^{43}$ and on the other hand, atherogenic effect of human lupus sera in vitro may be mediated by LDL-containing immune complex. ${ }^{44}$ Each cardiolipin molecule contains four unsaturated fatty acids, highly susceptible to oxidation. Mice sera with high titres of oxidised LDL antibodies, bind cardiolipin effectively only after oxidation. Therefore oxidative events may also play a major part in aCL formation. ${ }^{45}$ Because aCL may cross react with oxidised LDL antibodies, which recognise atherosclerotic lesions and not normal arteries, their association may not be incidental in the atherosclerosisprone dialysis patients. Indeed, in patients prone to arterial thrombosis, antioxidised LDL antibodies may be markers of antiphospholipid syndrome, and levels of antioxidised LDL antibodies are higher in these patients. ${ }^{46}$

LDL may also be involved in aCL associated vascular occlusion by inducing a prothrombotic state.

LDL itself may be a thrombogenic target of aCL, ${ }^{47}$ and raised concentrations of lipoprotein (a) in patients with aPL may inhibit the fibrinolytic pathway. ${ }^{48}$ Interestingly, in patients with SLE, $10 \%$ of aCL positive patients had a myocardial infarction. ${ }^{49}$

\section{Apoptosis}

Hypercoagulability in aPL may also be induced by apoptotic processes. Alterations of the phospholipid phase of cell membranes during late apoptosis are immunogenic and associated with the production of aPL. These surface alterations also have an independent procoagulant activity. ${ }^{50}$ Apoptotic cells may promote coagulation directly or via atherosclerotic plaque dislodgment.

Characteristic membrane blebbing, occurring in final stages of apoptosis may lead to the production of aPL and tissue factor procoagulant activity. Moreover, it has been claimed that via this pathway aPL may exert their hypercoagulability. ${ }^{50}$ Apoptotic inflammatory cells, such as macrophages and $\mathrm{T}$ cells, are found abundantly in atherosclerotic plaques and may induce plaque instability. Endothelial cell apoptosis may lead to loss of anticoagulant activity and increased leucocyte and platelet adhesion, resulting in rapid progression of the atherosclerotic and calcification process. ${ }^{50} \mathrm{On}$ the other hand, aPL may enhance apoptosis, with nuclear DNA fragmentation, cell lysis, and membrane disruption.

\section{Autoimmunity}

Pathogenecity of aPL depends on specificity, isotype, level, and duration of aCL. ${ }^{51}$ Cross regulatory roles of immunity and autoimmunity have recently emerged in vasculopathic and atherosclerotic processes. ${ }^{52} \mathrm{~A}$ prerequisite for this vascular autoimmunity is a humoral or cellular immune reactivity to self antigens, ${ }^{53}$ such as LDL turned immunogenic during oxidation and glycation and prompting $\mathrm{T}$ cell mediated immunity. ${ }^{54-57}$ 
Anti- $\beta 2 \mathrm{GpI}$ antibodies are of low affinity, supporting the need for $\beta 2 \mathrm{GpI}$-phospholipid interaction. In asymptomatic cases, the aCL is usually of low titre and of $\operatorname{IgM}$ isotype, while autoimmune aCL are predominantly $\mathrm{IgG}$, mainly $\operatorname{IgG}_{2}$ and $\operatorname{IgG}_{4}$, and high titre.

aPL IgM is not routinely considered significant, unless uniquely and persistently documented in hypercoagulable states.

\section{Genetic predisposition}

Most aCL are species specific recognising only human plasma. aCL are associated with class II major histocompatibility complex and in particular the DQB1 locus ${ }^{58}$ and DRw53, and either DR4 (in Caucasians) or DR7 (in Latinos). ${ }^{59}$ Genetic factors probably play an important part in the thrombogenic mechanism of aPL. ${ }^{27}$ Therefore, aCL may occur in genetically or immunologically susceptible haemodialysis patients, after a common infection or after recurrent endothelial insults and local thromboses.

$\mathrm{aCL}$ and anti- $\beta 2 \mathrm{GpI}$ antibody titre are usually well correlated. ${ }^{6061}$ The underlying explanation may be the varying affinities of aPL family to protein-phospholipid complex. Excluding $\beta 2 \mathrm{GpI}$, aCL may be directed against the complex of phospholipid and prothrombin, protein $\mathrm{C}$, and protein $\mathrm{S}^{38}$

\section{Therapeutic options for aCL associated vasculopathy}

Common practice mandates treatment only for aCL associated thrombosis and not for incidental finding of aCL. Possible options include oral anticoagulants with an ideal international normalised ratio of 3.5 , or aspirin and subcutaneous heparin. Glucocorticoids were beneficial in a few patients with aPL associated valvulitis. ${ }^{62} \mathrm{New}$ therapeutic strategies may also involve antioxidant agents in haemodialysis associated vascular events. ${ }^{45}$ Future prospects may include genetic modification of antithrombogenic nature of endothelial blood interface in vascular grafts by specific recombinant DNA insertion into seeded endothelial cells. ${ }^{63} \mathrm{~A}$ better understanding of the functional balance between positive and negative effects on endothelial cell proliferation may pave the way to new therapeutic prospects.

Table 1 Mechanisms possibly mediating anticardiolipin antibody associated vascular injury

\begin{tabular}{lll}
\hline Mechanism & Pathophysiology & References \\
\hline Endothelial activation & Platelet-endothelial interaction & $27-29$ \\
& Intimal hyperplasia & 28 \\
& Up-regulation of adhesion molecules & 31 \\
& Alteration of thromboxane A2-prostacyclin balance & 32 \\
& Endothelin-1 & 36 \\
Accelerated atherosclerosis & Cross reaction with oxidised LDL antibodies & 43,46 \\
& IL-1 secretion by macrophages & 41 \\
& Smooth muscle cells proliferation & 41 \\
Apoptosis & Thrombogenic effect of LDL and lipoprotein (a) & 43 \\
& Membrane blebbing & 30 \\
Autoimmunity & Apoptotic macrophages and T cells & 30 \\
& Endothelial cell apoptosis & 30 \\
Genetic predisposition & Humoral and cellular immunity for self antigens & 53 \\
& Immune recognition of LDL after oxidation and glycation & 54 \\
& T cell mediated immunity & 56,57 \\
& DQB1 locus, DRw53 locus & 58 \\
& DR4 in Caucasians and DR7 in Latinos & 59 \\
\hline
\end{tabular}

\section{Conclusions}

IgG aCL indicate chronic immunity, representing either a reaction to a primary endothelial injury, ${ }^{28}$ or playing a primary role in vascular occlusive disease. ${ }^{63}$ Vessel injury may determine the site of vascular thrombosis. ${ }^{20}$ Therefore, in patients with vascular disease a possible scenario may involve endothelial injury and membrane perturbation exposing neoantigens and adhesion molecules, ${ }^{64}{ }^{65}$ and the binding of aPL. An underlying genetic predisposition may be the link between recurrent endothelial insults and endogenous immune reaction in susceptible haemodialysis patients. Additionally, both oxidised LDL and the complex of altered $\beta 2 \mathrm{GpI}$ epitope and negatively charged phospholipids may be the targets of aCL, prompting the phospholipid dependent primary thrombosis. ${ }^{62}$ Thus, convergence of atherogenic risk factors and aCL associated thrombophilia may play an important part in vascular graft premature occlusion. However, on the other hand, aCL may be merely markers of vascular injury. ${ }^{14}$

It would be prudent therefore to conclude that whether aCL are endothelial platelet activators in vascular occlusions, or only play the part of "bystanders", is not currently known. Testing for aCL is essential for unexplained vascular occlusion. A prospective clinical study will better define the pathogenic role of aCL in the natural history of vascular occlusion disorders.

This review is summarised in table 1 .

1 Conley CL, Hartmann RC. A hemorrhagic disorder caused by circulating anticoagulants in patients with disseminated by circulating anticoagulants in patients with dissem

2 Bowie EJW, Thompson JH, Pascui CA, et al. Thrombosis in sytemic lupus erythematosus despite circulating anticoagulants. F Lab Clin Med 1963;62:416-30.

3 Vermlen J, Arnout J. Is the antiphospholipid syndrome caused by antibodies directed against physiologically relevant phospholipid-protein complexes? f Lab Clin Med 1992;120:10-12

4 Hunt JE, McNeil HP, Morgan GJ, et al. A phospholipid-beta 2 -glycoprotein I complex is an antigen for anticardiolipin antibodies occurring in autoimmune disease but not with infection. Lupus 1992;1:83-90.

5 Blank M, Faden D, Tincani A, et al. Immunization with anticardiolipin co (beta 2-glycoprotein) induces experimental antiphospholipid syndrome in naive mice. f Autoimmun tal antiphospholipid

6 Smirnov M, Triplett DT, Comp PC, et al. Role of phosphatidylethanolamine in inhibition of activated protein $\mathrm{C}$ activity by antiphospholipid antibodies. I Clin Invest 19995;9:309-16.

7 Lin R, Rehnder L. Acquired activated protein C resistance caused by factor Va antibody: a possible mechanism of increased thrombosis in the antiphospholipid antibody syndrome. Blood 1994;84(suppl):83a.

8 Oosting JD, Derksen RH, Bobbink IW, et al. Antiphospholipid antibodies directed against a combination of phospholipids with prothrombin, protein C or protein S: an explanation for their pathogenic mechanism? Blood 1993;81:261825.

25.

9 Funauchi M, Hamada K, Enomoto H, et al. Characteristics of the clinical findings in patients with idiopathic thrombocytopenic purpura who are positive for antiphospholipid antibodies. Internal Medicine 1997;36:882-5.

10 Exner T, Triplett DA, Taberner D, et al. Guidelines for testing and revised criteria for lupus anticoagulants. SSC Subcommittee for the Standardization of Lupus Anticoagulant. Thromb Haemost 1991;65:320-2.

11 Trent K, Neustater BR, Lottenberg R. Chronic relapsing thrombotic thrombocytopenic purpura and antiphospholipid antibodies. Am f Hematol 1997;54:155-9.

12 Rauch J, Janoff AS. Antibodies against phospholipids other than cardiolipin: potential roles for both phospholipid and protein. Lupus 1996;5:498-502.

13 Atsumi T, Khamashta MA, Amengual O, et al. Binding of anticardiolipin antibodies to protein $\mathrm{C}$ via $\beta 2$ glycoprotein 1 : a possible mechanism in the inhibitory effect of antiphospholipid antibodies on the protein C system. Clin Exp Immunol 1998;112:325-33. 
14 Roubey RAS. Autoantibodies tp phospholipid-binding plasma proteins: a new view of lupus anticoagulants and

5 Hunt JE, Simpson RJ, Krills SA. Identification of beta-2 glycoprotein 1 critical for lipid binding and anticardiolipin cofactor activity. Proc Natl Acad Sci US A 1996;90:2141-5

16 Gharavi AF, Sammaritano LR, Wen I, et al. Induction of antiphospholipid autoantibodies by immunisation with beta-2 glycoprotein 1. F Clin Invest 1992;90:1105-9.

17 Matsuura E, Igarashi Y, Fujimoto M, et al. Heterogeneity of anticardiolipim antibodies defined by the cardiolipin factor. f Immunol 1992;148:3885-91.

18 Triplett DA. Coagulation assays for the lupus anticoagulant: review and critique of the current methodology. Strok 1992;23:suppl 1-14.

19 Schved JF, Dupuy-fons C, Biron C, et al. A prospective epidemiological study on the occurrence of antiphospholipid antibody: the Montpellier antiphopholipid (MAP) study. antibody: the Montpellier antir

20 Levy PJ, Gonzalez MF, Hornung CA, et al. A prospective evaluation of atherosclerosis risk factors and hypercoagulaevaluation of atherosclerosis risk factors and hypercoagulability in young adults

21 Taylor LM, Chitwood RW, Dalmann RL, et al. Antiphospholipid antibodies in vascular surgery patients. A crosssectional study. Ann Surg 1994;220:544-50.

22 Gronhagen-Riska C, Teppo AM, Helanetra A, et al. Raised concentrations of antibodies to cardiolipin in patients receiving dialysis. BMF 1990;300:1996-7.

23 Kirschbaum B, Mullinax F, Curry N, et al. Association between anticardiolipin antibody and frequent clotting problems in hemodialysis (abstract). I Am Soc Nephrol 1991;2:332.

24 Garcia-Martin F, De Arriba G, Carrasoca T, et al. Anticardiolipin antibodies and lupus anticoagulant in end stage renal disease. Nephrol Dial Transplant 1991;6:543-7.

25 Bala Subramania V, Smith D, McMillan MA, et al. Anticardiolipin antibodies in long term dialysis patients (abstract). Nephrol Dial Transplant 1992;7:459.

26 Sitter T, Schiff H. Anticardiolipin antibodies in patients on regular hemodialysis: an epiphenomenon? Nephron 1993;64: 655-6 (letter)

27 Hojnik M, George J, Ziporen L, et al. Heart valve nvolvement in the antiphospholipid syndrome. Circulation 996;93:1579-87.

28 Westerman EM, Miles JM, Backonja M, et al. Neuropathologic findings in multi-infarct dementia associated with anticardiolipin antibody. Evidence for endothelial injury as the primary event. Arthritis Rheum 1992;35:1038-41.

29 Cockwell P, Tse WY, Savage CO. Activation of endothelia cells in thrombosis and vasculitis. Scand F Rheumatol 1997; 26:145-50.

30 Del Pappa N, Sheng YH, Rasci E, et al. Human $\beta 2$ glycoprotein 1 binds to endothelial cells through a cluster of lysine residues that are critical for anionic phospholipid binding and offers epitopes for anti $\beta 2$ glycoprotein 1 antibodies. Int Immunol 1998;160:5572-8.

31 Del-Pappa N, Raschi E, Catelli L, et al. Endothelial cells as a target for antiphospholipid antibodies: role of anti- $\beta 22$
glycoprotein I antibodies. Am 7 Reprod Immunol 1997;38: glycopr

32 Triplett DA. Lupus anticoagulant. In: Peter JB, Shoenfeld Y, eds. Autoantibodies. New York: McGraw-Hill 1996: 474-7.

33 Arese M, Strasly M, Ruva C, et al. Regulation of nitric oxide synthesis in uremia. Nephrol Dial Transplant 1995;10:138697.

34 Ooi BS, Papademetrious V, Cohen DJ. Demonstration of endothelial-activating properties of hypertensive sera. $A m \mathcal{F}$ Hypertens 1996;9(12 pt 1):1232-5.

35 Davies MG, Hagen PO. Alterations in venous endothelial cell and smooth muscle cell relaxation induced by high glucose concentrations can be prevented by aminoguanidine. $f$ Surg Res 1996;63:474-9.

36 Atsumi T, Khamashta MA, Haworth RS, et al. Arterial disease and thrombosis in the antiphospholipid syndrome: pathogenic role for endothelin 1. Arthritis Rheum 1998;41: pathogen.

37 Del Pappa N, Sheng YH, Raschi E, et al. Human beta-2 glycoprotein I binds to endothelial cells through a cluster of
lysine residues that are critical for anionic phospholipids lysine residues that are critical for anionic phospholipids
binding and offers epitopes for anti-beta 2 glycoprotein I binding and offers epitopes for anti-bet

38 Arnout J. The pathogenesis of the antiphospholipid syndrome: a hypothesis based on parallelisms with heparininduced thrombocytopenia. Thromb Haemostat 1996;75: 536-41

39 Tyagi SC, Smiley LM, Mujumdar VS, et al. Reductionoxidation (redox) and vascular tissue level of homocysteine in human coronary atherosclerotic lesions and role in extracellular matrix remodeling and vascular tone. Mol Cell Biochem 1998;181:107-16.
40 Appleton I, Brown NJ, Willis D, et al. The role of vascular endothelial growth factor in a murine chronic granulomatous tissue air pouich model of angiogenesis. F Pathol 1996; 180:90-4.

41 Couffinahl T, Kearney M, Witzenbichler B, et al. Vascular endothelial growth factor/vascular permeability factor in normal and atherosclerotic human arteries. Am f Pathol 1997; 150:1673-85.

42 Vaarala O, Alfthan G, Jauhiainen $M$. Cross-reaction between antibodies to oxidized LDL and to cardiolipin in systemic lupus erythematosus. Lancet 1993;341:923-5.

43 George J, Blank M, Hoinik M, et al. Oxidized LDL but not LDL aggravates the manifestations of experimental antiphospholipid syndrome (APS). Clin Exp Immunol 1997; 108:227-33.

44 Kabakov AE, Tertov VV, Saenko VA, et al. The atherogenic effect of lupus sera: systemic lupus erythematosus derived immune complexes stimulate the accumulation of cholesterol in cultured smooth muscle cells from human aorta. Clin Immunol Immunopathol 1992;63:214-20.

45 Horkko S, Miller E, Dudl E, et al. Antiphospholipid antibodies are directed against epitopes of oxidized phospholipids. Recognition of cardiolipin by monoclonal antibodies to epitopes of oxidized low-density lipoprotein. $\mathcal{F}$ Clin Invest 1996;98:815-25.

46 Amengual O, Atsumi T, Khamashta MA, et al. Autoantibodies against oxidized LDL in antiphospholipid syndrome. $\mathrm{Br}$ f Rheumatol 1997;36:964-8.

47 Koike T. Autoantibodies and thrombosis. Hokkaido fournal of Medical Science 1997;72:485-90.

48 Atsumi T, Khamashta MA, Andujar C, et al. Elevated plasma lipoprotein (a) level and its association with impaired fibrinolysis in patients with antiphospholipid syndrome. F Rheumatol 1998;25:69-73.

49 Koike T, Matsuura E. $\beta 2$-glycoprotein I and antiphospholipid syndrome. Isr f Med Sci 1997;33:225-38.

50 Takeya H, Tanaka Y, Suzuki K. Thrombosis and apoptosis. fapanese fournal of Clinical Pathology 1997;45:614-20.

51 Harris EN, Khamashata MA, Hughes GRV. Antiphospholipid antibody syndrome In: McCarty DJ, Koopman WJ, ed. Arthritis and allied conditions. 12th Ed. Philadelphia: Lea and Febiger, 1993: 1201-12.

52 George J, Harats D, Gilburs B, et al. Emerging crossregulatory roles of immunity and autoimmunity in atherosclerosis. Immunol Res 1996;155:315-22.

53 Shoenfeld Y, Isenberg DA. The mosaic of autoimmunity. Immunol Today 1989;10:123-6.

54 Stemme S, Faber B, Holm J, et al. T lymphocyes from human atherosclerotic plaques recognize oxidized low density lipoprotein. Proc Natl Acad Sci U S A 1995;92:3893-7.

55 Frostegard J, Wu R, Giscombe R, et al. Induction of T cell activation by oxidized low density lipoprotein. Arterioscler Thromb 1992;14:461-7.

56 Yla-Herttuala S, Palinski W, Butler SW, et al. Rabbit and human atherosclerotic plaques contain IgG that recognized epitopes of oxidized low density lipoprotein. Arterioscler Thromb 1994;14:32-40.

57 Lyons TJ. Lipoprotein glycation and its metabolic consequences. Diabetes 1992;41(suppl 2):67-73.

58 Wilson WA. Histocompatibility genes in antiphospholipid antibody syndrome. Lupus 1996;5:259-62.

59 Sebastini GD, Galeazzi M, Morozzi G, et al. The immunogenetics of the antiphospholipid syndrome, anticardiolipin antibodies, and lupus anticoagulant. Semin Arthritis Rheum 1996;25:414-20

60 Martinuzzo ME, Forastiero RR, Carreras LO. Anti $\beta$ GPI antibodies: detection and association with thrombosis. $\mathrm{BrF}$ Haematol 1995;89:397-402.

61 Viard JP, Amoura Z, Bach JF. Association of anti $\beta$ GPI antibodies with lupus-type circulating anticoagulant and thrombosis in systemic lupuis erythematosus. Am F Med 1992;82: 571-4

62 Nesher G, Ilany J, Rosenmann D, et al. Valvular dysfunction in antiphospholipid syndrome: prevalence, clinical features, and treatment. Semin Arthritis Rheum 1997;27:27-35.

63 Bacharach JM, Lie JT, Homburger HA. The prevalence of vascular occlusive disease associated with antiphospholipid syndrome. Int Angiol 1992;11:51-6.

64 Pidwell DJ, Heller MJ, Gabler D, et al. In vitro stimulation of human endothelial cells by sera from a subpopulation of high percentage panel reactive antibody patients. Transplantation 1995;60:563-9.

65 Del Pappa N, Meroni PL, Tincani A, et al. Relationship between antiphospholipid antibodies and anti endothelial antibodies: further characterization of the reactivity on resting and cytokine-activated endothelial cells. Clin Exp Rheumatol 1992;10:37-42. 